УДК 811.111: 81’42

DOI https://doi.org/10.32838/2710-4656/2021.5-1/17

Bilyk O. I.

Vasyl Stefanyk Precarpathian National University

Ivanotchak N. I.

Vasyl Stefanyk Precarpathian National University

Pyliachyk N. Ye.

Vasyl Stefanyk Precarpathian National University

\title{
METAPHORICAL PRESENTATION OF FUTURE IN THE AMERICAN ELECTION DISCOURSE
}

The article deals with the metaphorical actualization of the temporal concept FUTURE in the American election discourse. Any election campaign is closely connected with the vision of future and as the concept of time is extremely complex, this complexity calls for metaphorical understanding. In this study such metaphors as FUTURE IS A PATH, FUTURE IS A JOURNEY, FUTURE IS WAR, FUTURE IS A RECOVERY, FUTURE IS A VEHICLE, FUTURE IS A HOUSE, and FUTURE IS A HUMAN BEING are singled out and analysed. It is stated that the metaphors express positive or negative attitude of the speakers depending on their intention and purpose of communication.

The election discourse is characterized by a high level of manipulation which gives the possibility to assume that the use of certain strategies is a necessary part of manipulation in election discourse. So, special attention is paid to the activation of temporal metaphors within a strategy employed by the candidates. Such strategies as positive self-presentation and negative other presentation are considered and discussed in the study. The conceptual temporal metaphors of future are exploited by the politicians with the aim to forming a certain public view on political events in general and the course of the election in particular. Thus, the current research goes beyond the identification of metaphors in the election discourse. It goes a step further to interpret the way metaphors interact within the context and their function within communicative strategies employed by candidates.

The analysis of the metaphors with the FUTURE target domain shows that the politicians use these conceptual metaphors to foresee the future by developing plans, trying to form the right vision of future and make the life of the society better. In most cases the image of the future is metaphorised positively via the metaphors of path, journey, medicine, house, and human being within the strategy of positive self-presentation. Some metaphorical expressions from the source domains of war and path reveal negative aspects of the future within the opponent negative presentation strategy.

Key words: conceptual metaphor, temporal metaphor, FUTURE, source domain, target domain, election discourse.

Introduction. Studying the strategies of manipulation Paul Danler states that the aim of any political speech is to persuade the audience of selected political goals [2]. Political campaign discourse or election discourse possesses one encompassing goal: to win the election by convincing enough citizens to cast their votes for one candidate [1, p. 22]. So it is possible to say that election discourse is characterized by a high level of manipulation. Teun A. Van Dijk writes that manipulation involves: "enhancing the power, moral superiority and credibility of the speaker(s), and discrediting dissidents, while vilifying the others, the enemy..." [11, p. 380]. The use of certain strategies is a necessary part of manipulation in election discourse. The overall strategy of positive self-pres- entation and negative other presentation [1] is very typical in account of the facts in favour of the speaker's own interests, while blaming negative situations and events on opponents.

One of the main areas of discussion during the election campaign is analyzing the past, a critical assessment of the present, plans and prospects for the future. The cognitive process of creating a model of socio-political situation in the past, present and future is characterized by the use of various metaphors in the political communication. Time is considered to be more abstract concept than theatre, journey, family, food, and building. Awareness of the present as the time experienced at each moment, the past as the time related to remembered events, 
and the future as the time related to predicted events [10] calls for metaphorical understanding which enable people to simplify these complex and abstract concepts with the help of easily accessible and comprehensive ones. So the conceptual temporal metaphors of future definitely help form a certain public view on political events in general and the course of the election in particular.

Literature review. The ways of using specially chosen language units plays an important role in manipulating social cognition. Metaphors are considered to be effective persuasive devices in election discourse. They play a role in the creation of our social reality. Trying to understand metaphor means attempting to understand a vital part of what kind of world we live in [6]. Metaphors are important and necessary tools of politicians as political events are often abstract and too numerous for public consumption. They are considered to create political reality, shape our perception and lead to logical consequences [9, p. 121]. Since electors cannot pay attention to all aspects of election campaign process they need something to simplify decision making. In this case metaphor addresses this need. Besides, being manipulative tools of candidates, metaphors help achieve their main aim - to persuade people to vote for them.

For the purposes of the present study, metaphors are taken to be cases of figurative language in which one concept is understood in terms of another and in which features are transferred from one domain to another [3]. A conceptual domain is viewed as any coherent organization of people's experience [6,p. 4]. The analysis of metaphors presented in this article is based on the Conceptual metaphor theory by Lakoff and Johnson [7, p. 110] who distinguish such conceptual domains as source domain (the conceptual domain from which we draw metaphorical expressions) and target domain (the conceptual domain that we try to understand).

Metaphors are not only pervasive but also important in everyday life, in thought and action. They enable us to make sense of abstract concepts by conceptualizing the nonphysical in terms of the physical [7, p. 59]. Thus, conceptual metaphors typically employ a more abstract concept as target and a more concrete or physical concept as their source $[6, p .6]$ and in order to easily understand any nonphysical concept, one should exploit another more concrete and tangible concept than the former one for achieving this purpose. The experiences and connections with the physical world may serve as a natural background for understanding more abstract notions.
We think that under such circumstances it is reasonable to study the conceptual temporal metaphors used in election discourse and their manipulative power. The purpose of this paper is to provide a comprehensive linguistic analysis of the main metaphorical expressions used for conceptualization of the future and to study the role of these metaphors in the American election discourse.

The paper is based on the data from McCain's, Obama's and Romney's speeches, which they delivered in different locations during their presidential election campaign in the USA. The speeches were collected from the online resources and comprise transcripts of press conferences, nomination acceptance speeches, remarks, debates and interviews.

The methodology employed in the study is Critical Metaphor Analysis [4], which presents a basic framework for the linguistic analysis. Critical Metaphor Analysis (CMA) is based on Critical Discourse Analysis [5; 12] and Conceptual Metaphor Theory [6; 7] and aims to reveal the covert and possibly unconscious intentions of language users and expose conventionalized social hierarchies as they appear in linguistic references to conceptual metaphors [4, p. 34]. These approaches consider the incredible potential of metaphor as a political tool. There is the assumption that political elites exploit the rhetorical power of metaphor for their own political aims [8].

To begin the analysis, the entire corpus was given a close-reading and specifically studied for utterances which referenced three temporal category of future. Then, these highlighted utterances were further scrutinized for metaphorical expression at the textual and conceptual level. The found metaphorical expressions were then categorized into source domains (for example, path, war, journey) of conceptual metaphors of future. As metaphors convey a moral evaluation or an emotional slant on what is metaphorized, their role in contributing to positive or negative images of the metaphorized target was stated.

Results and discussion. Further the metaphorical linguistic expressions that can prove the existence of the conceptual metaphor FUTURE IS A PATH in the election discourse are presented: road, path, track, bend, climb, direction, horizon, frontier, to seek the road, to choose the path, to move in the right direction, to take a different path.

In the American election discourse, "I'm going to offer you what I believe is a better path forward, a path that will grow this economy", stated by Barack Obama, is one of the clearest cases of describing the future as a road. The metaphor "there's still a long 
road ahead', voiced by John McCain, is another example. Understanding life as a path is closely connected with journey that is why the path metaphor develops into the journey metaphor and they often appear together as in the following example: There is only the road we're traveling on as Americans and we will rise or fall on that journey as one nation; as one people (Barack Obama. Remarks in Reno, Nevada. September 30, 2008).

It seems that FUTURE IS A PATH and FUTURE IS A JOURNEY are so frequent because travelling, no matter how short the journey, is a universal experience that everyone can easily make sense of. Though these metaphors take part in the positive image of the future realization (a better path forward, a path to prosperity, the right direction) within the strategy of positive self-presentation, some metaphorical expressions from the path and journey domains (bumps in the road, a long road, a steep climb, a hill, a harder path) may evoke negative associations. Let us consider the following examples:

The journey will be difficult. The road will be long (Barack Obama. Remarks in St. Paul, Minnesota Claiming the Democratic Presidential Nomination Following the Montana and South Dakota Primaries. June 3, 2008).

But I was pretty certain and continue to be pretty certain that there are going to be bumps in the road... (Barack Obama. 60 Minutes Interviews with Obama and Romney, September 23, 2012).

I have no illusions about how far we have to go. Our road is still long. Our climb is still steep (Barack Obama. Remarks in Indianapolis, Indiana. May 3, 2008).

The candidate uses the linguistic expressions from the source domain of path to speak about some possible difficulties the country may face in the future. A difficult journey, bumps in the road or long roads are not the things travelers dream of. But the politician's intention is to show that he is aware of the obstacles and ready to overcome them. Besides with the help of the expressions our road and our climb the candidate tries to show that he will be together with people even in difficult situations.

It is obvious that a difficult journey or bumps in the road are not the things travelers (voters) dream of and these obstacles are extrapolated to future possible political and social problems, but the candidate turns to such metaphorical expressions to show the audience that he is a strong leader who is capable of choosing the right way and despite all the difficulties take the country to the final destination which he sees as the better future:
Now, I won't pretend the path I'm offering is quick or easy. The path we offer may be harder, but it leads to a better place; America, I never said this journey would be easy, and I won't promise that now. Yes, our path is harder, but it leads to a better place. Yes, our road is longer, but we travel it together. We don't turn back. We leave no one behind (Barack Obama. Remarks Accepting the Presidential Nomination at the Democratic National Convention in Charlotte, North Carolina. September 6, 2012).

Being connected with the idea of conflicts the metaphorical expressions from the source domain of war create a negative image of future and presuppose the existence of the conceptual metaphor FUTURE IS WAR: to fight for the future, to secure the future, to strive for over the next 5 years, to combat future threats, to attack, the future security, the front lines of the future, the threats of the future, a 100-year occupation, a long and hard and tough struggle; to win the fight for the future, to lose the fight for the future, to remain half-slave and halffree. The politicians often turn to this metaphor in the negative other presentation strategy but, if in case with the present which is understood in terms of war the criticism is aimed at the current political power, speaking about the future as war the candidates blame it on their opponents. According to Barack Obama due to the political strategies of John McCain "future is put in jeopardy" and he is "offering us a 100-year occupation". Notably John McCain also refers to the war metaphor to speak about the future but having military career he successfully uses this metaphor to employ the strategy of positive self-presentation:

I'm going to fight to make sure every American has every reason to thank God, as I thank Him: that I'm an American, a proud citizen of the greatest country on earth, and with hard work, strong faith and a little courage, great things are always within our reach. Fight with me. Fight with me. Fight for what's right for our country. Fight for the ideals and character of a free people. Fight for our children's future (John McCain. Address Accepting the Presidential Nomination at the Republican National Convention in Saint Paul. September 4, 2008). Thus, the high concentration of war metaphors within one excerpt is a strong indicator that the emphasis is not so much on the bad future as on personal qualities of the speaker who is immensely experienced in war events.

So within the strategy of self-presentation the candidates exploit the war metaphor, firstly, to show the audience the ability to fight for the country and its people in every sphere of life as in: It will be a choice between two different paths for America, a choice 
between two fundamentally different visions for the future. Ours is a fight to restore the values that built the largest middle class and the strongest economy the world has ever known...(Barack Obama. Remarks Accepting the Presidential Nomination at the Democratic National Convention in Charlotte, North Carolina. September 6, 2012). Secondly, the politicians want to prove the necessity of their socio-political plans such as "to recruit a generation of new teachers, an army of new teachers, especially in math and science, give them higher pay" because "they're (teachers) on the front lines of our country's future" (Barack Obama. Remarks at a Campaign Rally in North Las Vegas, Nevada. August 22, 2012).

In terms of the disease metaphor the future is opposed to the negative present and is understood as a recovery from the disease that stands for the present. This metaphor is often employed in positive self-presentation strategy and is realized in the binary temporal opposition "negative present :: positive future": When I'm president, I'm going to make real changes that lead to a real recovery, so that the next four years are better than the last (Mitt Romney. Statement by Mitt Romney on the October Unemployment Report. November 2, 2012). Though some possible difficulties in the future are viewed as short-term pain the image of the future conceptualized in terms of medical metaphor appears to be positive. On analyzing metaphorical expressions from the source domain of medicine it was found out that the present and the future are conceptualized differently which results in conceptual metaphors PRESENT IS A DISEASE and FUTURE IS A RECOVERY.

Let us consider the FUTURE IS A VEHICLE metaphor, which produces linguistic metaphors such as "millions of new jobs, many in industries that will be the engine of our future prosperity" stated by John McCain and "the industries and the jobs that will fuel our future" produced by Barack Obama. The candidates employ the mechanical metaphor in the positive self-presentation strategy as speaking about the future as a vehicle the engine and fuel stand for millions of new jobs and industries they are planning to create and develop. This metaphor also implies a driver that stands for the certain candidate who will become the president and will steer the nation in the right direction.

If in the American election discourse the mechanical metaphor contributes to creating a positive image of the future, the conceptual metaphor with the financial source domain draws the audience's attention to some negative aspects of the future as illustrated by the examples below:
We let earmarking and corrupt spending get to the point where we mortgaged our kids' futures (John McCain. Interview with Larry King of CNN. July 28, 2008).

I think it's immoral for us to continue to spend our kids'future year after year, trillions of dollars passed onto the next generation, knowing we can't possibly pay it back (Mitt Romney. Remarks in Des Moines Following the Iowa Caucuses. January 3, 2012).

I've seen crumbling schools in South Carolina that are stealing the future of black children and white children. (Barack Obama. Remarks in El Dorado, Kansas: "Reclaiming the American Dream". January 29, 2008).

From very early on, people living in human society have engaged in economic transactions of various kinds. These transactions often involve the use of money and commodities in general [6, p. 18]. That is why metaphorical expressions from the financial source domain are so powerful in manipulating people. Notably the metaphors mortgaged our kids futures, spend our kids'future, stealing the future of black children and white children paint a negative picture of the future in the temporal opposition "negative present :: negative future". The financial metaphor is thus used to attribute blame for the future failures to those who is responsible for the present problems. The fact that the present events will influence the future of kids implies that the present politics will have long lasting results. Only the metaphorical expressions invest it in your future and the single most important investment you can make in your future from the speeches of John McCain and Barack Obama respectively paint a positive picture of the future as the speaker talk about their politics.

Another way to conceptualize the future in the context of the presidential election is a group of metaphors that emphasize the dynamics of society and belong to source domain of building. The reason for the use of these metaphors is that the building process is associated with positive changes as in the following excerpt:

I want to wake up and know that every single American has health care when they need it, that every senior has prescription drugs they can afford, and that no parents are going to bed at night worrying about how they'll afford medicine for a sick child. That's the future we can build together. That's the choice you'll have this fall. And that's why I'm running for President of the United States of America (Barack Obama. Remarks in Bristol, Virginia. June 5, 2008).

The source domain of building produces a conceptual metaphor FUTURE IS A HOUSE which the can- 
didates employ within the positive self-presentation strategy to paint a positive picture of the future:

And if we want to get people working again and that's my priority - if we want to get people working again, we have to celebrate success and achievement and not demonize it and denigrate the people who have worked hard, who are smart, who have made the kinds of investments to build a brighter future (Mitt Romney. CNBC Exclusive: CNBC Transcript: Republican Presidential Candidate Mitt Romney Speaks one-on-one with Larry Kudlow Today on CNBC. July 23, 2012);

The house is an important concept in the system of human experience and a traditional metaphorical source domain. The domain of house is related to people's everyday life, is familiar and close to every person, because the house is the main most comfortable sphere of human in general and family in particular existence. For example, doors allow entry and exit, as well as protect against unwanted guests. In the FUTURE IS A HOUSE metaphor, doors stand for new opportunities that lead to a better future as proved by the following examples:

The door to a brighter future is there, open, waiting for us (Mitt Romney. Remarks in West Allis, Wisconsin: "Real Change From Day One". November 2, 2012).

New doors are open for us to sell our ideas and our products to the entire world (Mitt Romney. Remarks on the Economy in Ames, Iowa. October 26, 2012).

The source domain is a human being which helps us understand a non-human target domain of future. People can conceptualize nonhuman things in terms of a human because it is related to them and what is closer and familiar to a person's life and experience is definitely easier to understand. The positive vision of the future is invoked by the metaphors that present the future as a young person because America's youth are ... our future (Barack Obama), a person one can embrace or feel a special kinship with (Mitt Romney). The future is somebody on the behalf of whom the candidates are ready to work every single day, tirelessly (Barack Obama). The FUTURE IS A HUMAN BEING metaphor produced metaphorical expressions to indicate people's jobs: worker is the fundamental strength and future, entrepreneurs like Martha and Dorene are the future for America, farmers are America's future. Such metaphors evoke pleasant emotions as make people of differents professions think they are important for the country and its future. Thus the metaphors from the source domain of human being help the candidates paint a picture of positive future thus implementing the strategy of positive self-presentation.

Conclusion. The present study has been concerned with the metaphorical representation of the temporal concept FUTURE in the American election discourse. As metaphors are vehicles of hidden meanings, used by candidates as a discursive practice with a precise strategic aim and intent in mind [3, p. 18], special attention has been devoted to the activation of metaphors within certain strategy employed by the candidates. The metaphorical conceptualization of the future in the election discourse gives the empirical evidence for metaphor as a persuasive device as the candidates effectively created the images of good/ bad future for positive self-presentation or disqualifying some political developments, authorities or even their opponents. While positive metaphors are used to paint a pleasant picture of life experiences at a certain period of time, negative metaphors have a great potential to dramatically change the opinion of public.

A great number of metaphorical realisations and various metaphors from different source domains activated for conceptualization of the future indicate the tendency of the candidates to foresee the future by building plans, trying to predict the development of the society and make its life better. The analysed material proves that the metaphorical conceptualization of the future is characterized by a great number of metaphors which paint a positive picture of the future and are employed by the candidates within the strategy of self-presentation. Some negative aspects are revealed by the metaphors from the source domains of war, path and finance. But the overall positive image prevails in the conceptualization of the future and proves the idea of 'a better future' which underlies the basic idea of progress.

Being manipulative by nature election discourse has a great number of concepts that are understood metaphorically and this variety calls for further study which can reveal many interesting aspects.

\section{References:}

1. Benoit, W. L. (2000). Let's Put 'Debate' into Presidential Debates. Rostrum.

2. Danler, P. (2005). Morpho-syntactic and textual realizations as deliberate pragmatic argumentative linguistic tools? https://doi.org/10.1075/dapsac.17.04dan

3. Cammaerts, B. (2012). The strategic use of metaphors by political and media elites: The 2007-11 Belgian constitutional crisis. International Journal of Media \& Cultural Politics, 8(2), 229-249. http://dx.doi.org/10.1386/ macp.8.2-3.229_1 
4. Charteris-Black, J. (2004) Corpus Approaches to Critical Metaphor Analysis. NY: Palgrave Macmillan.

5. Fairclough, N. and Wodak, R. (1997) Critical discourse analysis. In T. van Dijk (ed.), Discourse Studies: A Multidisciplinary Introduction, Vol. 2. London: Sage. pp. 258-286.

6. Kövecses, Z. (2002). Metaphor: A Practical Introduction. New York : Oxford University Press.

7. Lakoff, G., \& Johnson, M. (1980). Metaphors We Live By. University of Chicago Press: Chicago.

8. Meadows, B. (2007). Distancing and showing solidarity via metaphor and metonymy in political discourse: A critical study of American statements on Iraq during the years 2004-2005. Critical approaches to discourse analysis across disciplines, 1(2), 1-17.

9. Mio, J. (1997). Metaphor and Politics. Metaphor and Symbol. Metaphor and symbol, 12 (2), 113-133. DOI:10.1207/s15327868ms1202_2

10. Radden, G. (2003). The Metaphor TIME AS SPACE across Languages. Zeitschrift für Interkulturellen Fremdsprachenunterricht, 8 .

11. Van Dijk, T. A. (2006). Discourse and manipulation. Discourse and society, 17, 359-383.

12. Wodak, R. (2007). Pragmatics and Critical Discourse Analysis. A cross-disciplinary inquiry. Pragmatics and Cognition, 15(1), 203-225. http://dx.doi.org/10.1075/pc.15.1.13wod

\section{БіЛИК О. І., ІваНоТчаК Н. І., ПиЛЯчИК Н. Є. МЕТАФОРИЧНА ПРЕЗЕНТАЦІЯ МАЙБУТНЬОГО В АМЕРИКАНСЬКОМУ ПЕРЕДВИБОРЧОМУ ДИСКУРСІ}

У статті розглядається метафорична актуалізація темпорального концепту МАЙБУТНЄ в американському передвиборчому дискурсі. Будь-яка передвиборча кампанія тісно зв 'язана з баченням майбутнього, $i$, оскільки концепт часу є складним поняттям, він потребує метафоричного пояснення для кращџого його розуміння. У дослідженні виділено й описано метафори FUTURE IS A PATH, FUTURE IS A JOURNEY, FUTURE IS WAR, FUTURE IS A RECOVERY, FUTURE IS A VEHICLE, FUTURE IS A HOUSE, $i$ FUTURE IS A HUMAN BEING. Проаналізовано також позитивний $і$ негативний потенціал метафор і доведено, щзо він залежсть від намірів і мети мовия.

Передвиборчий дискурс характеризується високим ступенем маніпуляиії, і ие дає змогу припускати, що використання відповідних стратегій є невід'ємною частиною маніпуляиії в передвиборчому дискурсі. Тому особливу увагу привертає активачія темпоральних метафор у межах стратегії, яку використовує кандидат у президенти. У статті виокремлено та розглянуто такі стратегї̈, як позитивна самопрезентація та негативна презентація інших. Концептуальні темпоральні метафори майбутнього в передвиборчому дискурсі використовуються політиками з метою вплинути на формування громадської думки на політичні події загалом і на хід розвитку виборів зокрема. Тому дослідження має на меті не просто ідентифікувати та проаналізувати темпоральні метафори майбутнього, а й розглянути та описати, як інтерпретація метафори залежить від контексту і як комунікативні стратегії, які використовуються кандидатами, впливають на функиіонування метафор.

Аналіз кониептуальних метафор із референтом FUTURE показує, що кандидати в президенти використовують иі метафори, щоб передбачити майбутній розвиток країни; політики також намагаються сформувати правильний образ майбутнього і вплинути на формування суспільної думки щодо того, яким має бути майбутнє і яким воно стане за умови перемоги того чи іншого кандидата. Здебільшого створюється позитивний образ майбутнього через метафори иляху, подорожі, дому і людини в межах стратегії позитивної самопрезентації. Деякі метафоричні вирази, що належать до сфер-джерел війни і шляху, розкривають негативні сторони майбутнього в межах стратегії негативної презентації опонента.

Ключові слова: концептуальна метафора, темпоральна метафора, майБутнє, сфера-джерело, сфера-иіль, передвиборчий дискурс. 